\title{
Post-Phenomenology, Transduction, and Speculative Fabulations
}

\author{
Róisín Lally ${ }^{1}$
}

Accepted: 11 December 2020 / Published online: 3 June 2021

(c) The Author(s) 2021

\begin{abstract}
This response briefly argues that post-phenomenology has always cut across the transcendental-empirical divide and is able to cultivate a deep respect for technologies in their otherness, without denying their relation to humanity. It does this by revisiting Don Ihde's genetic phenomenological variations and tracing its relation to Gilbert Simondon's ontogenesis. Having set up the historical nature of objects, the second part of this paper will take up Yoni Van Den Eede's call for a more speculative approach.
\end{abstract}

Keywords Transduction · Ontogenesis · Anthropocentrism $\cdot$ Technology $\cdot$ Speculative fabulations

Calling on the spatial and causal imagery of the lever, Yoni Van Den Eede sites his work between what he sees as two terms of the of major opposition in the philosophy of technology today: the empirical and the transcendental. He elaborates on this in his new book, The Beauty of Detours: A Batesonian Philosophy of Technology, where he claims we are wedged between two uses; instrumental purposiveness and a vaguer, more elusive existential purposiveness. ${ }^{1}$ The task in "Thing-Transcendentality: Navigating the Interval of 'technology' and "Technology" is to "bridge" this central dichotomy from an existential standpoint. It begins by outlining several objections to post-phenomenology, many of which appear in this issue of Foundations of Science. ${ }^{2}$ The second section follows the detours of the well-trodden path where he distinguishes between "Technology/T" and "technology/t:" The former are the conditions of

\footnotetext{
1 Van Den Eede, (2019 p. 233). "Thing-Transcendentality: Navigating the Interval of "technology" and "Technology" in The Beauty of Detours: 232.

2 It should be noted that Don Ihde recently points to convergences in Feenberg's critical constructivism which he has now coined "postcritical theory" and postphenomenology specifically fallibilism where both postphenomenology and postcritical theory espouse changes in technology impacts that are open to "nudges." This also applies to similarities Ihde sees between Feenberg's "Gestalt switches" and "multistabilities.".
}

This comment refers to the article available online at https://doi.org/10.1007/s10699-020-09749-y.

Róisín Lally

lally@gonzaga.edu

1 Gonzaga University, Spokane, WA, USA 
possibility that give rise to technology, the latter are concrete engaged practices. To fertilize the "wasteland" that occupies the gap between these two, sections three and four introduce Graham Harman's object-oriented ontology (OOO) and Timothy Morton's object-orientated literary criticism, making way for Van Den Eede's post-phenomenology that is "more object-oriented, but sensibly." In so doing, he nudges post-phenomenology towards speculative realism.

Why is this speculative element important? What has speculation got to do with postphenomenology? Have we not spent four decades explicitly twisting free from metaphysical undertones as part of a lineage that goes back at least to Kant? The problem as Van Den Eede sees it is that as we find ourselves amidst an ecological crisis, we struggle to have empathy for non-sentient things. Nature is in trouble. We are witnessing the scorching earth beneath our feet on a daily basis. Responding to nature, he argues, requires a non-anthropocentric ontology, one that levels the ontological status of humans and objects. Van Den Eede's solution is to practice "object empathy." In this regard I think he is correct. We do need to think through the ecological crises, which means we must move beyond the anthropocentrism of modernity. To do this we need the tools of speculative philosophy and speculative art. Calling on the philosophy of Donna Haraway and the art of Piccinini is something I have argued since my first work on my $\mathrm{PhD}$. But does post-phenomenology need $\mathrm{OOO}$ to do this? And must a philosophy eschew a relational ontology in order to overcome anthropocentrism? This response briefly argues that post-phenomenology has always cut across the transcendental-empirical divide and is able to cultivate a deep respect for technologies in their otherness without denying their relation to humanity. It does this by revisiting Don Ihde's genetic phenomenological variations and tracing its relation to Gilbert Simondon's ontogenesis. For Ihde, technics means both the purposiveness and the materiality of technology. ${ }^{3}$ As such it is a horizontal and vertical integration of time not reducible to epochal sways. He refers to this as a thing's "shelf life" (Ihde 2019, p. 3). This is similar to what I call "transductional" time 4 and is precisely the historical-phenomenology Ihde develops in his writing analysis. Having set up the historical nature of objects, the second part of this paper will take up Van Den Eede's call for a more speculative approach and argues that the speculative fabulations of Donna Haraway provide an inspiration more in line with the ethos of post-phenomenology. Here we see a similar coherence between transductional time, shelf life, and what Haraway calls "wild" time, where she uses metaphors to imagine the new world of chimeras that are already in our midst, beings that whether we like it or not, are related to us and whose quality of life will depend on our choices Thus, I agree with Van Den Eede that we must cut across the transcendentalempirical divide, move beyond anthropocentrism, and make a place for the speculative and I am open to the possibility that OOO may provide resources to do so. But it is important to note that these have always been themes internal to post-phenomenology.

\section{Ihde's Transduction}

We live in a world that discloses itself through high level technologies: nuclear energy, massive communications and medical systems, highly technologically mediated food production, complex information technologies, etc. This complex matrix of material practices

\footnotetext{
3 Ihde (2019 p. 2).

4 For a more complete analysis of ontogenesis see Lally (2019 pp. 83-99).
} 
means we are increasingly embodying ${ }^{5}$ these technologies and this trend has accelerated since Husserl and Heidegger's death. Ihde's examples of embodied beings include technologies that extend our temporal existence such as pacemakers, computational and information technologies that extend our cognitive powers, and the construction of cyborgs as a prosthetic extension of our organic bodies in cybernetics.

To make sense of these technological transformations, Ihde argues that we must make a methodological shift from the modernist phenomenological tradition to what he coins "postphenomenology." At the heart of the project are differentiations between stability and multistability, between technologically embodied beings and pre-technical conscious acts, and between technological determinism and technological evolution-differences, he argues, that are overlooked by Husserl (Ihde 2016) and Heidegger (Ihde 2010). Ihde concludes that a pure phenomenology is only appropriate when talking about an unreflective life without technology. As bodies in technology, we no longer live in this purely phenomenological world. The demarcation is clear for Ihde while Husserl overlooks materially-mediated technologies almost entirely, Heidegger thinks that human beings are involved with technology. Ihde argues, further, that we are embodied in technology and so there is no ontological priority of human beings (Ihde 2002). Ihde's correction to phenomenology, therefore, is to do an analysis of how the body interacts with the world through technology. Advancing the philosophy of technology (Winner, Feenberg, Lynn White, Mumford, Ellul, etc.), he argues that we are not merely making the world, for as we embody technology, we are making the self—or, more precisely, technology and humanity are co-constituting. This is an evolving process, sometimes continuous with previous inventions, sometimes breaking with conventional technologies, but always changing. This involves an entire "gestalt of changes" that becomes "individualized" though time. ${ }^{6}$ Contrary to the neutrality/non-neutrality debate and the Heideggerian analysis of the essential nature of technology, Ihde is interested in such things as the existential import of the loss of past cultures, the present dystopian/utopian views of human-technology relations, and the existential futural question of the technological stabilized "ensemble" (Ihde 1990, p. 7). In this way, the transcendental conditions for the coming into being of technology and the empirical particularities of its being are always already entangled. One way that I have argued that this becomes manifest is through a comparison with the work of Gilbert Simondon.

Simondon calls the "ensemble" a "metastable equilibrium," which is "the conservation of being through becoming." 7 This movement is referred to as transduction and is the condition of possibility of a thing coming into existence, the ontogenesis of being:

[Transduction is] characterized by the fact that the result of this process is a concrete network including all the original terms. [It] is characterized by the conservation of information, whereas induction requires a loss of information. ... transduction does not presuppose the existence of a previous time period to act as a framework in which the genesis unfolds, time itself being the solution and dimension of the discovered systematic: time comes from the preindividual just like the other dimensions that determine individuation. ${ }^{8}$

\footnotetext{
${ }^{5}$ Phenomenologically, the syntheses between instrument and body overcomes the distinction between lifeworld and the "world of science" and becomes for Ihde the "embodied" relation of science and life-world. In this sense we are already cyborgs. "Cyborgs [are] creatures simultaneously animal and machine, who populate worlds ambiguously, natural and crafted...the boundary between human and animal is thoroughly breached... [and a] second leaky distinction is between animal-human (organism) and machine." Cf. Ihde (2002, 89). On cyborgs see Haraway (1991 pp. 149-181).

6 Ihde (1990 p. 5).

7 Simondon (1992) p. 301. See Lally (2019) for a full analysis of transduction.

8 Simondon (2017 315).
} 
Ihde's variational theory follows the same structure evidenced throughout his entire corpus. Writing as a technology, for example, and using Simondon's language, has "conserved some information" for 20,000 years. This conservation of information is evolutionarily determined only by degree as all technologies are subject to temporal existence-and thus cannot be exhaustively treated by any transcendental idealism. In Husserl's Missing Technologies (2016) Ihde presents Husserl's "history" of writing as the closest Husserl gets to a material hermeneutics.

Written signs are, when considered from a purely corporal point of view, straightforwardly, sensibly experienced ... Accordingly, then, the writing-down affects a transformation of the original mode of being of the meaning-structure, within the geometrical sphere of self-evidence, of the geometrical structure that is put into words... it becomes sedimented, so to speak. But the reader can make it self-evident again, can reactivate the self-evidence. (Husserl's Missing Technologies, 53).

Ihde interprets this as the linguistic meaning-structure that is embodied in actual speech. "Sound is sensibly experienceable and its meanings can be intersubjectively understood." But writing transforms the bodily presentation to a visible mode and to one which is "fixed" or repeatable. In this sense it is doubly "materialized." This can be thought of as transductive. Both the evolution and the trace of its evolutionary past remain as in-formation. In this way, Ihde's variational theory can be said to be transductive.

Why might this be important? Is this an attempt to smuggle in a nostalgic desire for a time gone by? Is the very idea of trying to recover a relation to a "forgotten" time the antithesis of a post-phenomenological account of experience? I hope to defend a postphenomenological analysis of the historical possibilities inherent in materiality in Ihde's analysis, which I can do by revisiting his reinterpretation of Heidegger's phenomenological description of the temple in Heidegger's Technologies.

Ihde reminds us that historically the temple was also a destructive power. During the establishment and building of Athens, the natural world was used as Bestand, ${ }^{10}$ which resulted in the desertification of the Attic Peninsula as Plato was already aware. ${ }^{11}$ The gathering of the fourfold into the Parthenon threatened the environment. Ihde uses this example to point to the current ecological crisis. Building great empires is not a simple construction. The Greek gathering of the fourfold was destructive. Ihde, thus, sees Heidegger as embedded in a world of ambiguity where the preservers of the earth are at one and the same time the group of people who often reign terror over their own land. Recognizing this, he thinks, will lead to a more balanced assessment of technology.

What is needed is not a rejection of the deep and essentially phenomenological insights into technology as a culturally embedded phenomenon with its different gestalt features, but a deepening and more complex appreciation of all of the facets of our technologically textured modern life ... including both the politics of our artifacts, and the demythologization of nostalgic and romantic views of previous times .... ${ }^{12}$

\footnotetext{
${ }^{9}$ Ihde (2016 54).

${ }^{10}$ Ihde (2010 75).

${ }^{11}$ Bonfiglioli (2019 pp. 3-27).

12 Ihde (2010 p. 75).
} 
For Ihde, Heidegger's critique of technology has only regional or limited relevance, particularly as it is tied to a demonizing of the present and a glorification of the past. But this is not a rejection of genetic phenomenology in which the conditions that give rise to technologies are given no concern. On the contrary, Ihde is sensitive to how a thing's shelf-life persists over time. One might even say the essence of the thing is how it persists in time. So, if by transcendental we mean that which gives rise to particular technologies, and by that Ihde includes political structures, then Ihde here clearly does not reject transcendental philosophy. Nevertheless, Van Den Eede is correct when he says that post-phenomenology "does not like the transcendental," 13 and this is for the same reasons that motivate Van Den Eede and the adherents of Speculative Realism: namely, the desire to overcome anthropocentrism. To the extent that the understanding forces reality into its categories, ideality is to be rejected. What Ihde shows us is that the "material" counterpart to this empiricism is the tendency for embodiment technologies to cultivate the illusion of total transparency in which the technology disappears completely from view and the "here-body" becomes the absolute locus of meaning. Further, embodiment relations then become the paradigm for all technologies. This is why Ihde leads us from embodied technologies toward hermeneutic and, eventually, alterity technologies. ${ }^{14}$

Both Ihde and OOO want to overcome this anthropocentrism. But Van Den Eede seems to suggest that, on the OOO view, this can only be done by abandoning a human-technology relational ontology altogether. This would be true only if Levinas were correct that all ontology is the violence of war and an empiricism from which there is no escape. ${ }^{15}$ Obviously, I cannot tackle such an imposing topic here, but I want to end with a more open-ended suggestion that highlights the parallels with Van Den Eede's contribution. To respond to environmental catastrophe means overcoming anthropocentrism; overcoming anthropocentrism means integrating the empirical and the transcendental and turning to the speculative. While Ihde's project is oriented around the former, an explicit engagement with the latter could be more developed-while remaining within the orbit of post-phenomenology_ by emphasizing the work of Donna Haraway.

\section{Infolding the Gap in Post-phenomenology}

Donna Haraway explicitly joins the turn to the speculative and the turn away from the anthropocentric - without leaving behind the relational. She writes, "Technologies are not mediations, they are not something in between us and another bit of the world-rather, technologies are organs, full partners, in what Merleau-Ponty called 'infoldings of the flesh." "16 However, unlike speculative realism, she denies technologies have essential natures. Rather, infoldings are always worldly. She writes, "syntactically and materially,

\footnotetext{
13 Van Den Eede, (2019 p. 3).

14 "Within embodied technologies, where the technology were to intrude upon rather than facilitate one's perceptual and bodily extension into the world, the technology's objectness would necessarily have appeared negatively. Within hermeneutic relations, however, there emerged a certain positivity to the objectness of instrumental technologies." Ihde (1990, p. 96). "It is my strategy to treat alterity last: to undercut the Heideggerian negativity and objectivism... what is needed is an analysis of the positive or presentential senses in which humans relate to technologies as relations to or with technologies, to technologyas-other. It is this sense which is included in the term 'alterity."' (Ibid p. 98).

15 See Levinas, Totality and Infinity, first page of the Preface.

16 Haraway (2006 pp. 175-196, p. 175).
} 
worldly embodiment is always a verb, or at least a gerund. Always in formation, embodiment is ongoing, dynamic, situated, and historical." 17 As with Haraway, Simondon, and my own "transductional time," 18 this is an evolving process, sometimes continuous with the past, sometimes radically innovative, but always changing. These changes are materially embodied and thus resist full assimilation to human understanding or human desires. Technologies are the interweaving of stories that have no clear beginnings or endings; they are what build ways of living and dying, of living socially and culturally within the dance of infoldings. However, this does not mean we need to abandon all human perspectives.

Technology is a relational matrix of humans and non-humans that shapes and is shaped by skill, dream, need, power, community: there is no outside and there is no narrative structure with origins followed by good or bad endings. Technology is about what developmental biologists call 'reciprocal inductions.' These infoldings and inductions shape who and what lives and dies and how. ${ }^{19}$

Deeply attuned to the changing landscape of technologies, those that resist our full conscious awareness, Haraway draws on myth and metaphor to understand the complexities of the world we are creating. In response to the work of Australian artist, Patricia Piccinini, she was struck by the call to "learn how to confront the complexities of the new world in order to be able to move toward multi-species reconciliation." ${ }^{20}$ Piccinini's art proposes to claim another time and place for vulnerable creatures of diverse species and generations. It is tuned to cultivate practices of care and risk on-going face-to-face encounters with unexpected partners in the age of the chimera, a call very similar to object-empathy.

Certainly, there are important similarities here with the proponents of 000 . They, too, appeal to art and myth to speculate about a transcendent world beyond human consciousness. For example, Timothy Morton writes,

When OOO says object, it means any entity whatsoever: symphonies, grass, poems, wind, nebulae, wind harps, plays, humans, spools of thread, porpoises. Since objects are prior to any relation, and since causality (including time and space) just is a series of relations between things, causality must be ontologically "in front" of objects. This space "in front" traditionally reserved the aesthetic. ${ }^{21}$

Further, the aesthetic, as Morton sees it, is metaphor. "When one object influences another one, it does so by translating that object." 22 Calling on the Greek link between translation and metaphor, he sees that the ground of causality is in fact, metaphor. To understand causality, therefore, is to translate a metaphor. This is all very much in line with Piccinini and Haraway. The next step, which seems so clear to Morton, is one I would hesitate to take. "How to proceed? We should merely release the anthropocentric copyright control on correlationism, allowing nonhumans like fish (and perhaps even fish forks) the fun of not being able to access the in-itself" (2016, 18; original emphasis). The jump to the in-itself seems unwarranted. I agree with Van Den Eede's call for a post-phenomenology that is object-oriented but sensibly, and I agree that we need a speculative element to our philosophy in order to

\footnotetext{
17 Ibid p. 176.

18 Lally (2019 pp. 90, 91, 94).

19 Haraway 94.

20 Orgaz, L. F. and Patricia Piccinini (2007).

21 Morton (2012 pp. 205-225, pp. 205-206).

${ }^{22}$ Harman (2005 pp. 91-93, pp. 98-99, pp. 101-24).
} 
overcome anthropocentrism. But I question the speculative approach of Morton and find it unnecessary in light of the more aesthetically attuned ontology of genesis we get with Simondon and Haraway. They allow us to include a speculative element in the philosophy of technology that remains rooted in the phenomenological tradition, and yet goes beyond phenomenology by giving an account of [the non-apparent sources of appearing] [the invisible] [what does not appear-or has not yet appeared.] Speculative philosophy, for me, must be centered on fabulations, technofantasies, and imaginings of human beings while remaining grounded in materiality. As I write these words, Australia is consumed in a burning inferno. As the ferocity of nature's destructiveness is amplified by human technology, both the intrinsic value of the more-than-human world and the necessity of cultivating speculative art and philosophy to creatively discover new relations with it seem more vital than ever.

Open Access This article is licensed under a Creative Commons Attribution 4.0 International License, which permits use, sharing, adaptation, distribution and reproduction in any medium or format, as long as you give appropriate credit to the original author(s) and the source, provide a link to the Creative Commons licence, and indicate if changes were made. The images or other third party material in this article are included in the article's Creative Commons licence, unless indicated otherwise in a credit line to the material. If material is not included in the article's Creative Commons licence and your intended use is not permitted by statutory regulation or exceeds the permitted use, you will need to obtain permission directly from the copyright holder. To view a copy of this licence, visit http://creativecommons.org/licenses/by/4.0/.

\section{References}

Bonfiglioli, C. P. (2019). Sustainability: A single word and a world of meanings. In R. Lally (Ed.), Sustainability and the anthropocene: Philosophical essay on renewable technologies (pp. 3-27). Washington: Lexington Books.

Brown, N. (2013) The Nadir of OOO: From Graham Harman's Tool-Being to Timothy Morton's Realist Magic: Objects, Ontology, Causality. In Parrhesia, Number 17, 2013, pp. 62-71. Open Humanities Press.

Haraway, D. J. (2006). Crittercam: Compounding eyes in naturecultures. In E. Selinger (Ed.), PostphenomenologyA critical companion to Ihde. New York: State University of New York.

Haraway, D.J. (1991). Simians, cyborgs and women: The reinvention of nature. New York: Routledge.

Harman, G. (2005). Guerrilla metaphysics: Phenomenology and the carpentry of things. Chicago: Open Court.

Ihde, D. (2010). Heidegger's technologies: Postphenomenologcial perspectives. New York: Fordham University Press.

Ihde, D. (2016). Husserl's missing technologies. New York: Fordham University Press.

Ihde, D. (2019). Medical technics. Minneapolis: The University of Minnesota Press.

Ihde, D. (1990). Technology and the lifeworld. From garden to earth. Bloomington: Indiana University Press.

Ihde, D. (2002). Bodies in technology (p. 2002). Minneapolis, London: University of Minnesota Press.

Lally, R. (2019). The ontogenesis of wind turbines and the question of sustainability. In R. Lally (Ed.), Sustainability and the anthropocene: Philosophical essay on renewable technologies (pp. 3-27). Washington: Lexington Books.

Morton, T. (2012). An object-oriented defense of poetry. In New Literary History, Vol. 43, 2. The John Hopkins University Press. Retrieved Jan 5, 2020, from https://www.jstor.org/stable/pdf/23259372.pdf.

Orgaz, L. F., \& Patricia P. (2007). The naturally artificial world. Tender Creatures, exhibition catalogue.

Simondon, G. (2017) On the mode of existence of technical objects. Trans. Cecile Malaspina and John Rogove. Minneapolis: Univocal Publishing.

Simondon, G. (1992). The genesis of the individual. In C. Johnathan \& K. Sandford (Eds.), Incorporations. New York: Zone Books. 
Róisín Lally is a Lecturer of Philosophy at Gonzaga University. Drawing on the traditions of philosophy of technology, postphenomenology, and phenomenology she works at the intersection of philosophy of time, philosophy of the environment, and ethics. Her most recent edited collected is called Sustainability in the Anthropocene: Philosophical Essays on Renewable Technologies (Lexington Books, 2019), recommended by CHOICE. She is the author of several articles and chapters. Currently she is editing two books, Contemporary Irish Phenomenology and Women Philosophers of Technology. Her monograph Being, Time, Technology is due for completion in 2021. Her new research interest, "The Ontogenesis of Artificial Wombs: The Ethical Implications of Biobags," is grounded in what she calls transductional time, influenced by Gilbert Simondon's Ontogenesis and New Materialism. 